\title{
JUURNAL_RU
}

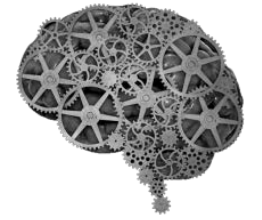

COMPANY GROUP "INTELLEKT"

Вонаршенко А.П., Борейчук А.Ф., Засядько К.И., Язлюк М.Н.
Липеикий Государственный педагогический университет Липецк, Россия

doi: 10.18411/lj2016-7-1-03

idsp 000001: lj2016-16-1-03

\section{Повышение функциональных возможностей респираторной системы у школьников с заболеваниями органов дыхания путём использования специальных физических упражнений}

В последние годы в Российской Федерации наблюдается возрастание количество школьников, отнесенных по состоянию здоровья к специальным медицинским группам, связанных с заболеваниями органов дыхания. Поэтому оздоровительно-реабилитационные мероприятия, направленные на улучшение функции системы дыхания младших школьников, приобретают особое значение [5].

Целью работы явилось экспериментальное обоснование, разработка и оценка эффективности комплекса специальных физических упражнений для повышения функциональных возможностей дыхательной системы [3] детей специальных медицинских групп с заболеваниями органов дыхания.

В исследовании приняли участие 22 школьника младших классов в возрасте 9-10 лет специальной медицинской группы с заболеваниями органов дыхания. По данным исходного тестирования были образованы две репрезентативные группы по 11 школьников, контрольная и экспериментальная. В контрольной группе уроки физической подготовки проводились по общепринятой программе для специальных медицинских групп [2]. В экспериментальной группе применялась разработанная нами методика специальных физических упражнений, которая заключалась в том, что в 
подготовительную, основную и заключительную часть урока включались подобранные комплексы физических упражнений, направленных на улучшение функции дыхания.

В подготовительную часть урока включались упражнения дыхательной гимнастики (для брюшного и грудного дыхания, на задержку дыхания), упражнения для снятия бронхоспазма, нормализации механики дыхания, восстановления стереотипа регуляции дыхания.

В основную часть урока включались статические и динамические дыхательные упражнения, дыхательные упражнения для дыхательной мускулатуры и подвижности грудной клетки, гимнастические упражнения для мышц брюшного пресса и плечевого пояса.

В заключительную часть занятия включались дыхательные упражнения А.Н. Стрельниковой, упражнения йоги-цигун $[1,4]$.

Тестирование по завершению эксперимента показало, что у школьников экспериментальной группы отмечаются достоверные более высокие значения исследуемых показателей по сравнению со значениями показателей школьников контрольной группы.

Так, значения показателей жизненной емкости легких, характеризующие степень развития дыхательной мускулатуры и функциональную способность органов дыхания, в процессе эксперимента увеличились в контрольной группе на 122 мл (7,1\%), в экспериментальной - на 214 мл (11,5\%).

Сравнительный анализ значений показателей окружности грудной клетки, характеризующих развитие дыхательных мышц, выявил, что в контрольной группе увеличение произошло на 2,1 см (3,0%), в экспериментальной на 5,7 cм $(9,0 \%)$.

Значения показателей пробы Штанге увеличились в контрольной группе на 2,3 с (10,7\%), в экспериментальной группе на 7,5 c (32,6\%). Значения показатели пробы Генчи увеличились в контрольной группе на 2,2 с (11,3\%), в 
экспериментальной группе на 7,8 с $(30,4 \%)$. Полученные различия имеют достоверный характер $(\mathrm{p}<0,05)$.

Значения индекса Руфье, характеризующие адаптацию сердечнососудистой системы к физическим нагрузкам, в начале эксперимента оценивались как слабые в обеих группах, в конце эксперимента в контрольной группе улучшение значений данного показателя произошло на 2,3 усл. ед. и составило 11,1 усл. ед., что соответствует слабому результату, в экспериментальной группе - удовлетворительному (7,2 усл. ед.).

Таким образом, выполнение по предложенной методике специально подобранных физических упражнений школьниками 9-10 лет показало их эффективность для улучшения функционального состояния системы дыхания и кровообращения по сравнению с уроками по общепринятой программе для специальных медицинских групп. 


\section{Литература:}

1. Минвалеев, Р. С. Физиологические аспекты избранных асан хатха-йоги. / Р. С. Минвалеев - СПб.: Изд-во С.-Петерб. ун-та, 2014. - С. 103.

2. Рипа, М.Д. Занятия физической культурой со школьниками, отнесенными к специальной медицинской группе/ М.Д. Рипа, В.К. Велитченко, С.С. Волкова - М.: Просвещение, 1988 - С. 175.

3. Ольховская, Е.А. Исследование функции внешнего дыхания: учебнометодическое пособие/ Е.А. Ольховская. - Нижний Новгород, 2014.-С. 60.

4. Щетинин, М.Н. Дыхательная гимнастика Стрельниковой / М.Н. Щетинин. М.: Метафора, 2007-С. 128.

5. Яйленко, А.А. Возможности и перспективы оценки состояния здоровья с позиции теории адаптации/ А.А. Яйленко // Роль спортивной медицины и ЛФК в развитии оздоровительной физкультуры и спорта высших достижений: материалы международной научно-практической конференции/ под ред. В.Н. Костюченкова, В.Е. Шаробаро. Смоленск.:2013 - С. 147-149. 